\title{
Health Financing Functions in Community Based Health Insurance Schemes and Health Equity in Kenya
}

\author{
Jane G. Gitahi ${ }^{1}$ \& Timothy C. Okech ${ }^{2}$ \\ ${ }^{1}$ Doctorate canditate at United States International, Africa \\ ${ }^{2}$ Associate Professor of Economics, United states International Universaity, Africa \\ Correspondence: Gitahi W. Jane, Doctorate candidate, United States International University, Africa. Tel: \\ 254-72-649-5058. E-mail: jane6277@gmail.com
}

\author{
Received: September 4, 2017 Accepted: October 9, 2017 Online Published: December 6, 2017 \\ doi:10.5539/gjhs.v10n1p147 \\ URL: https://doi.org/10.5539/gjhs.v10n1p147
}

\begin{abstract}
The aim of this study was to establish how the healthcare financing functions are modeled within CBHIs and how they have impacted on realization of health equity with government stewardship being treated as the moderating factor. The study adopted descriptive and explanatory research designs to collect data from four members each management team of all registered CBHIs in Kenya. Descriptive statistics, factor analysis, path analysis and multivariate regression analysis in terms of structural modeling equation (SEM) were conducted to determine the hypothesized relationships between the health financing functions and their impact on health equity in Kenya. The study shows that enrolment and strategic purchasing in CBHIs accounted for variation in health equity in terms of increasing access to quality healthcare services. With the introduction of government stewardship as the moderating factor, the variation of health equity accounted for by enrolment and strategic purchasing increased. It was therefore inferred that the government should define the place of CBHIs within the context of the national health financing policy for realization of health equity by instituting the necessary legal and regulatory framework.
\end{abstract}

Keywords: health financing, stewardship, health equity, risk pooling, strategic purchasing

\section{Introduction}

Disparities and inequities in healthcare are increasingly being recognized as core in policy debates and dialogue in healthcare. Disparities in healthcare access and high levels of financial risks associated with healthcare payments have been documented with a number cited in low and middle income countries (LMICs). Globally an estimated 400 million people lack access to essential health services, with $17 \%$ considered either impoverished or pushed deeper into poverty by healthcare costs (Starfield, 2011; WHO, 2015a; Asante, Price, Hayen, Jan, \& Wiseman, 2016). Almost a third of households in Africa and South East Asia regions (SEAR) of World Health Organization (WHO) member states are forced to borrow money or sell assets to pay for healthcare (Kruk, Godmann, \& Galea, 2009).

Enormous discrepancies in healthcare expenditure are evident among countries with LIMCs relying heavily on out of pocket (OOP) expenditure to finance healthcare. In 2013, households in LIMCs contributed $42.3 \%$ and $40.6 \%$ respectively of Total Health Expenditure (THE) compared to 21.2\% in high income countries (WHO, 2016). Additionally, while poorer countries in African and SEAR of WHO account for over half of global burden of disease and 39\% of world's population they spent only 3\% of world health resources in 2012 (WHO, 2015b). Further, the WHO African region and SEAR are deprived of access to quality healthcare due to large deficits of skilled health workers. The ensuing disparities in access to quality healthcare and financial protection places equity at the heart of current policy debates of Universal Health Coverage (UHC) and in the post 2015 Sustainable Development Goals (SDGs) agenda (WHO, 2015c). UHC was founded on the principle of access to healthcare for all with financial risk protection while SDGs are founded on the theme of inclusiveness.

The desire to enhance financial risk protection and improve access to quality healthcare services is core in health financing. The important challenge however is in developing health financing mechanisms that guarantee access to quality healthcare and offer financial protection for all. Health financing encompasses three functions; revenue collection (includes enrolment rates and mix of contributions), risk pooling and strategic purchasing functions. Revenue collection involves raising of funds; risk pooling encompasses accumulation and use of the funds in 
equalization of financial risks associated with ill health while strategic purchasing involves sourcing for cost effective and quality health services from healthcare providers and paying for them (WHO, 2010). Government stewardship is critical for steering the implementation of these functions since the government bears the ultimate responsibility for the health of its people (WHO, 2000).

Governments world over have the ultimate responsibility for ensuring all segments of the population obtain services they need without suffering financial ruin associated with their utilization (WHO, 2000). Beyond the formal health structures, government stewardship is often hypothesized as a critical determinant of successful and sustainable health financing in community based structures such as CBHIs (Preker \& Carrin, 2004). Various authors have different views of how appropriately the state can play the role of stewardship in CBHIs. Bennett, Creese \& Monash (1998) construe that even where a clear government policy does not exist, the schemes are still likely to play a critical role of increased health equity. However, the schemes role in the broader health system will remain largely undefined. Carrin, Waelkens \& Criel (2005) view stewardship as critical to encouraging enrolment across different income categories. Mladovsky \& Mossialos (2006) view government stewardship as critical to the success of the schemes on condition that the government adapts them as a strategy for achieving its equity and UHC objectives. On the contrary, Pauly et al. (2006) advocates for minimal government regulation citing an increase of cream skimming and adverse selection in presence of government subsidies. This study examined how the health financing functions are carried out in CBHIs under government stewardship in terms of design of CBHIs, monitoring CBHIs related activities, training and financing, and how they impact on health equity in Kenya.

\section{Methodology}

The methods in the study focused on gathering data from all registered Kenyan CBHI's on enrollment, mix of contributions, risk pooling, strategic purchasing, government stewardship and health equity. Data was collected from four members of each respective CBHI management team with questionnaires using a five point likert-type scale and further assessed by Cronbach's alpha coefficients, as well as average variance extracted (AVE) and Kaiser-Meyer-Olkin (KMO) values to determine standardized regression rates. The data was further refined using elimination methods where the factors with low standardized regression rates were deleted.

\section{Results}

This section presents the descriptive statistics, Cronbach's Alpha Coefficients, AVE and KMO values for enrolments, mix of contributions, risk pooling, strategic purchasing and government stewardship and the test for hypothesized relationship of moderating effect of government stewardship on health financing functions and health equity.

The study shows that $91.5 \%$ of CBHIs covered up to 500 households with the average enrolment across the studied CBHIs estimated at 169 households. CBHIs enlist services from providers that are accredited by National Health Insurance Fund (NHIF) and that majority of the CBHIs offer composite products in conjunction with NHIF that cover medical expenses in private hospitals.

SmartPLS was used to measure the construct, composite and convergent reliability as well as discriminant validity. Construct reliability was assessed by computing the composite reliability and the Cronbach alpha of the constructs at a threshold of 0.6. AVE was used to measure convergent validity which estimates that ability of indicators relevant latent constructs to actually measure a particular construct. A 0.5 threshold was adapted indicating that the latent constructs should account for at least fifty percent of the variance in the items. Discriminant validity was measured using KMO at thresholds of 0.5. Only items significance levels of each test were retained for further analysis. Table 1 presents the summary of the Cronbach's Alpha Coefficients, AVE and KMO values for the exogenous variables. 
Table 1. Cronbach's Alpha Coefficients, AVE and KMO values for Exogenous Variables

\begin{tabular}{|c|c|c|c|c|c|c|c|c|}
\hline $\begin{array}{l}\text { 2nd order } \\
\text { construct }\end{array}$ & $\begin{array}{l}\text { First order } \\
\text { constructs }\end{array}$ & $\begin{array}{l}\text { Cronbach's } \\
\text { alpha }\end{array}$ & Item & $\begin{array}{l}\text { Item total } \\
\text { correlation }\end{array}$ & КМO & $\begin{array}{l}\text { PCA } \\
\text { component } \\
\text { loading }\end{array}$ & $\begin{array}{l}\text { variance } \\
\text { extracted }\end{array}$ & Items deleted \\
\hline \multirow{11}{*}{ 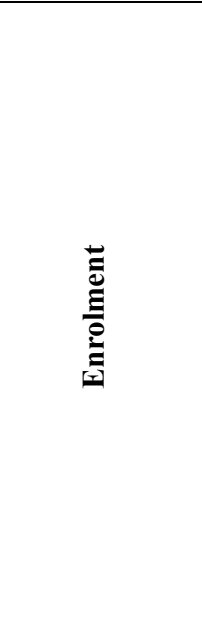 } & Affordability & 0.964 & AF1 & 0.931 & 0.763 & 0.983 & $96.57 \%$ & \multirow{2}{*}{$\mathrm{AF} 2, \mathrm{AF} 3, \mathrm{AF} 4$} \\
\hline & & & AF4 & 0.931 & & 0.983 & & \\
\hline & \multirow[t]{2}{*}{ Membership } & 0.977 & MT1 & 0.956 & 0.500 & 0.989 & $97.78 \%$ & \multirow{2}{*}{ MT2, MT3 } \\
\hline & & & MT4 & 0.956 & & 0.989 & & \\
\hline & \multirow{2}{*}{$\begin{array}{l}\text { Timing of } \\
\text { collections }\end{array}$} & 0.939 & TM1 & 0.886 & 0.500 & 0.971 & $94.29 \%$ & \multirow{2}{*}{ TM1, TM2, TM4 } \\
\hline & & & TM3 & 0.886 & & 0.971 & & \\
\hline & Trust & 0.934 & TRU1 & 0.770 & 0.766 & 0.864 & $71.45 \%$ & None \\
\hline & & & TRU2 & 0.850 & & 0.907 & & \\
\hline & & & TRU3 & 0.764 & & 0.859 & & \\
\hline & & & TRU4 & 0.825 & & 0.892 & & \\
\hline & & & TRU5 & 0.561 & & 0.685 & & \\
\hline \multirow{2}{*}{$\begin{array}{l}\text { Mix of } \\
\text { Contribution }\end{array}$} & 0.714 & $\mathrm{MC} 2$ & 0.523 & 0.500 & 0.715 & $51.11 \%$ & \multicolumn{2}{|l|}{$\mathrm{MC} 1, \mathrm{MC} 3$} \\
\hline & & MC4 & 0.523 & & 0.715 & & & \\
\hline \multirow{5}{*}{$\begin{array}{l}\text { Enhanced } \\
\text { risk pooling }\end{array}$} & 0.816 & ERP1 & 0.669 & 0.602 & 0.79 & $83.73 \%$ & \multirow{5}{*}{\multicolumn{2}{|c|}{ ERP2, ERP5, ERP7 }} \\
\hline & & ERP3 & 0.761 & & 0.969 & & & \\
\hline & & ERP4 & 0.525 & & 0.993 & & & \\
\hline & & ERP6 & 0.586 & & 0.957 & & & \\
\hline & & ERP8 & 0.559 & & 0.834 & & & \\
\hline \multirow{4}{*}{$\begin{array}{l}\text { Strategic } \\
\text { purchasing }\end{array}$} & 0.876 & SP1 & 0.702 & 0.802 & 0.832 & & $73.95 \%$ & \multirow{4}{*}{ SP5 } \\
\hline & & $\mathrm{SP} 2$ & 0.603 & & 0.777 & & & \\
\hline & & SP3 & 0.821 & & 0.91 & & & \\
\hline & & SP4 & 0.793 & & 0.892 & & & \\
\hline
\end{tabular}

The results presented in Table 1 show that Cronbach's alpha coefficients were above the 0.7 threshold for all first order constructs; the total item correlations were above 0.3 ; AVE were above $65 \%$; KMO values were greater than 0.5 and the satisfactory principal component loadings were above 0.50 . The factors with low standardized regression weights like AF2, MT2, TM2, MC3, ERP5, SP5 among others were subsequently deleted. These findings imply that the items of measure were measuring what they were initially set out to measure, and therefore the data was maintained for further analysis. 
Table 2 presents the summary of the Cronbach's Alpha Coefficients, AVE and KMO values for the moderating variable.

Table 2.Cronbach's Alpha Coefficients, AVE and KMO values for Government Stewardship

\begin{tabular}{|c|c|c|c|c|c|c|c|}
\hline $\begin{array}{l}\text { First order } \\
\text { constructs }\end{array}$ & $\begin{array}{l}\text { Cronbach's } \\
\text { alpha }\end{array}$ & Item & $\begin{array}{l}\text { Item total } \\
\text { correlation }\end{array}$ & KMO & $\begin{array}{l}\text { PCA } \\
\text { component } \\
\text { loading }\end{array}$ & $\begin{array}{l}\text { variance } \\
\text { extracted }\end{array}$ & $\begin{array}{l}\text { Items } \\
\text { deleted }\end{array}$ \\
\hline \multirow{10}{*}{ Design } & \multirow[t]{10}{*}{0.876} & $\mathrm{AD} 1$ & 0.902 & \multirow[t]{10}{*}{0.956} & 0.920 & \multirow[t]{10}{*}{$90.23 \%$} & \multirow[t]{10}{*}{ None } \\
\hline & & AD2 & 0.948 & & 0.958 & & \\
\hline & & AD3 & 0.954 & & 0.963 & & \\
\hline & & AD4 & 0.920 & & 0.935 & & \\
\hline & & AD5 & 0.960 & & 0.968 & & \\
\hline & & AD6 & 0.966 & & 0.973 & & \\
\hline & & AD7 & 0.938 & & 0.950 & & \\
\hline & & AD8 & 0.922 & & 0.937 & & \\
\hline & & AD9 & 0.932 & & 0.945 & & \\
\hline & & AD10 & 0.936 & & 0.949 & & \\
\hline \multirow{2}{*}{ Monitoring } & \multirow[t]{2}{*}{0.958} & MO1 & 0.919 & \multirow[t]{2}{*}{0.5} & 0.980 & \multirow[t]{2}{*}{$95.97 \%$} & \multirow[t]{2}{*}{ None } \\
\hline & & MO2 & 0.919 & & 0.980 & & \\
\hline \multirow{7}{*}{ Training } & \multirow[t]{7}{*}{0.986} & TR1 & 0.934 & \multirow[t]{7}{*}{0.913} & 0.952 & \multirow[t]{7}{*}{$92.19 \%$} & \multirow[t]{7}{*}{ None } \\
\hline & & TR2 & 0.959 & & 0.970 & & \\
\hline & & TR3 & 0.962 & & 0.973 & & \\
\hline & & TR4 & 0.945 & & 0.959 & & \\
\hline & & TR5 & 0.951 & & 0.964 & & \\
\hline & & TR6 & 0.967 & & 0.976 & & \\
\hline & & TR7 & 0.901 & & 0.926 & & \\
\hline \multirow{2}{*}{ Co-financing } & \multirow[t]{2}{*}{0.903} & COF1 & 0.823 & \multirow[t]{2}{*}{0.5} & 0.955 & \multirow[t]{2}{*}{$91.13 \%$} & \multirow[t]{2}{*}{ None } \\
\hline & & $\mathrm{COF} 2$ & 0.823 & & 0.955 & & \\
\hline
\end{tabular}

The results presented in Table 2 show the Cronbach's alpha coefficients, total item correlations, AVE, KMO values and satisfactory principal component loadings met the statistical thresholds. The data was therefore maintained for further analysis. 
Table 3 presents the summary of the Cronbach's Alpha Coefficients, AVE and KMO values for the endogenous variable.

Table 3. Cronbach's Alpha Coefficients, AVE and KMO values for Health Equity

\begin{tabular}{|c|c|c|c|c|c|c|c|}
\hline Health Equity & $\begin{array}{l}\text { Cronbach's } \\
\text { alpha }\end{array}$ & Item & $\begin{array}{l}\text { Item total } \\
\text { correlation }\end{array}$ & KMO & $\begin{array}{l}\text { PCA } \\
\text { component } \\
\text { loading }\end{array}$ & $\begin{array}{l}\text { variance } \\
\text { extracted }\end{array}$ & $\begin{array}{l}\text { Items } \\
\text { deleted }\end{array}$ \\
\hline \multirow[t]{4}{*}{ Healthcare access } & 0.833 & $\mathrm{ACC} 1$ & .551 & 0.786 & .725 & $67.19 \%$ & None \\
\hline & & $\mathrm{ACC} 2$ & .707 & & .848 & & \\
\hline & & $\mathrm{ACC} 3$ & .693 & & .846 & & \\
\hline & & $\mathrm{ACC} 4$ & .712 & & .852 & & \\
\hline \multirow[t]{3}{*}{ QOC } & 0.961 & QOC1 & .956 & 0.722 & .981 & $92.79 \%$ & \\
\hline & & QOC8 & .930 & & .969 & & \\
\hline & & QOC9 & .868 & & .939 & & \\
\hline \multirow[t]{4}{*}{$\mathrm{AMC}$} & 0.953 & $\mathrm{AMC1}$ & .947 & 0.812 & .976 & $88.52 \%$ & \\
\hline & & $\mathrm{AMC} 2$ & .945 & & .973 & & \\
\hline & & AMC3 & .905 & & .952 & & \\
\hline & & AMC6 & .767 & & .858 & & \\
\hline \multirow[t]{5}{*}{ Sustainability } & 0.909 & FS1 & .848 & 0.784 & .917 & $73.84 \%$ & \\
\hline & & FS2 & .785 & & .862 & & \\
\hline & & FS5 & .740 & & .838 & & \\
\hline & & FS8 & .702 & & .795 & & \\
\hline & & FS10 & .792 & & .880 & & \\
\hline
\end{tabular}

The results summarized in Table 3 show that Cronbach's alpha coefficients, total item correlations, AVE, KMO values and satisfactory principal component loadings met the statistical criteria hence the data was maintained for further analysis.

The validity of the theoretical measurement model was measured against the sample data collected by evaluating the path coefficients, $t$-values, overall model fit and significance levels for the structural paths to determine the causal relationships among the research constructs as hypothesized in the integrative model. Bootstrapping was used to measure the strength and direction of the hypothesized relationship. Initially, the significance testing of the independent variables was conducted without the mediator. The mediating variable (government stewardship) was then included in the model and the resultant $\mathrm{t}$ - values were generated. The second assessment of model fit allowed evaluation of the fitness of the integrative model and individual parameters estimates for the structural paths in the structural regression model. The statistical objective of PLS is to show the $\mathrm{r}^{2}$ and significant $t$-values. Parameters with an absolute $t$-value greater than 1.96 indicate a significance level of 0.05 (i.e. $p<0.05$ ). Figures $1,2,3$ and 4 and tables 4 and 5 presents the paths coefficients, standard deviations, t-statistics and P values for the overall model without moderation and the moderated overall model. 


\subsection{Optimum Model without Moderation}

Table 4. Path Coefficients (Mean, STDEV, t-Values)

\begin{tabular}{llllll}
\hline & $\begin{array}{l}\text { Original Sample } \\
(\mathrm{O})\end{array}$ & $\begin{array}{l}\text { Sample Mean } \\
(\mathrm{M})\end{array}$ & $\begin{array}{l}\text { Standard Deviation } \\
(\mathrm{STDEV})\end{array}$ & $\begin{array}{l}\text { T Statistics } \\
(|\mathrm{O} / \mathrm{STDEV}|)\end{array}$ & P Values \\
\hline $\begin{array}{l}\text { Enrolment }-> \\
\text { Equity }\end{array}$ & 0.473319 & 0.476809 & 0.147603 & 3.206705 & 0.001429 \\
\hline $\begin{array}{l}\text { Purchasing } \\
->\text { Equity }\end{array}$ & 0.495651 & 0.493281 & 0.148596 & 3.335560 & 0.000915 \\
\hline
\end{tabular}

Figure 1 shows that the endogenous latent variable health equity had a coefficient $\mathrm{r}^{2}$ mean of 0.882 implying that out of the four exogenous variables only two exogenous variables; Enrolment and Strategic Purchasing explain $88.2 \%$ of variation in health equity. Enrolment account for $47.3 \%$ of variation in health equity while Strategic Purchasing account for $49.5 \%$ of variation health equity. Figure 2 suggests that the hypothesized paths between Enrolment and health equity $(\beta=3.207)$ and Strategic Purchasing and health equity $(\beta=3.336$ are significant at 0.05 level of significance.

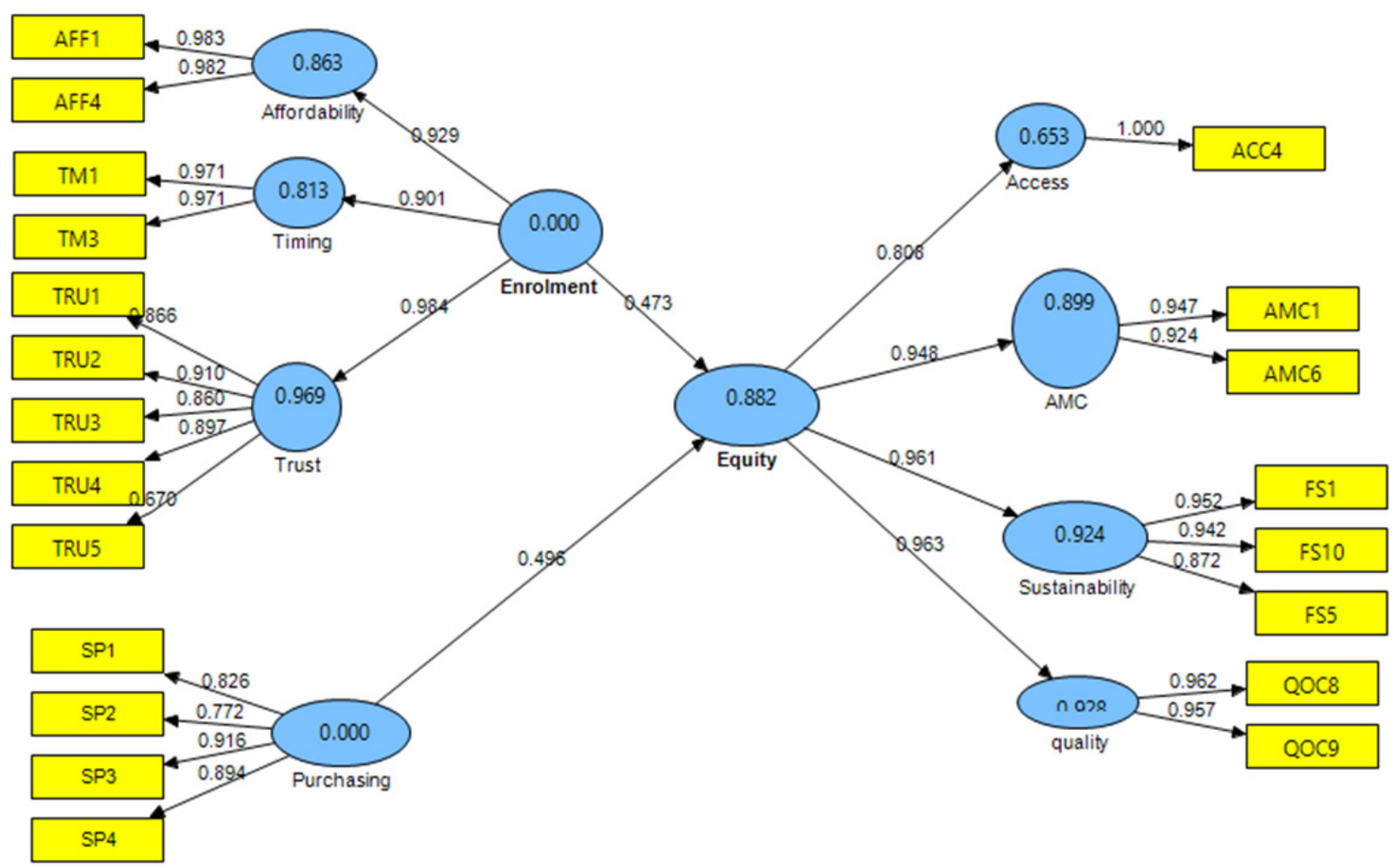

Figure 1. Path coefficients for the optimum model without moderation 


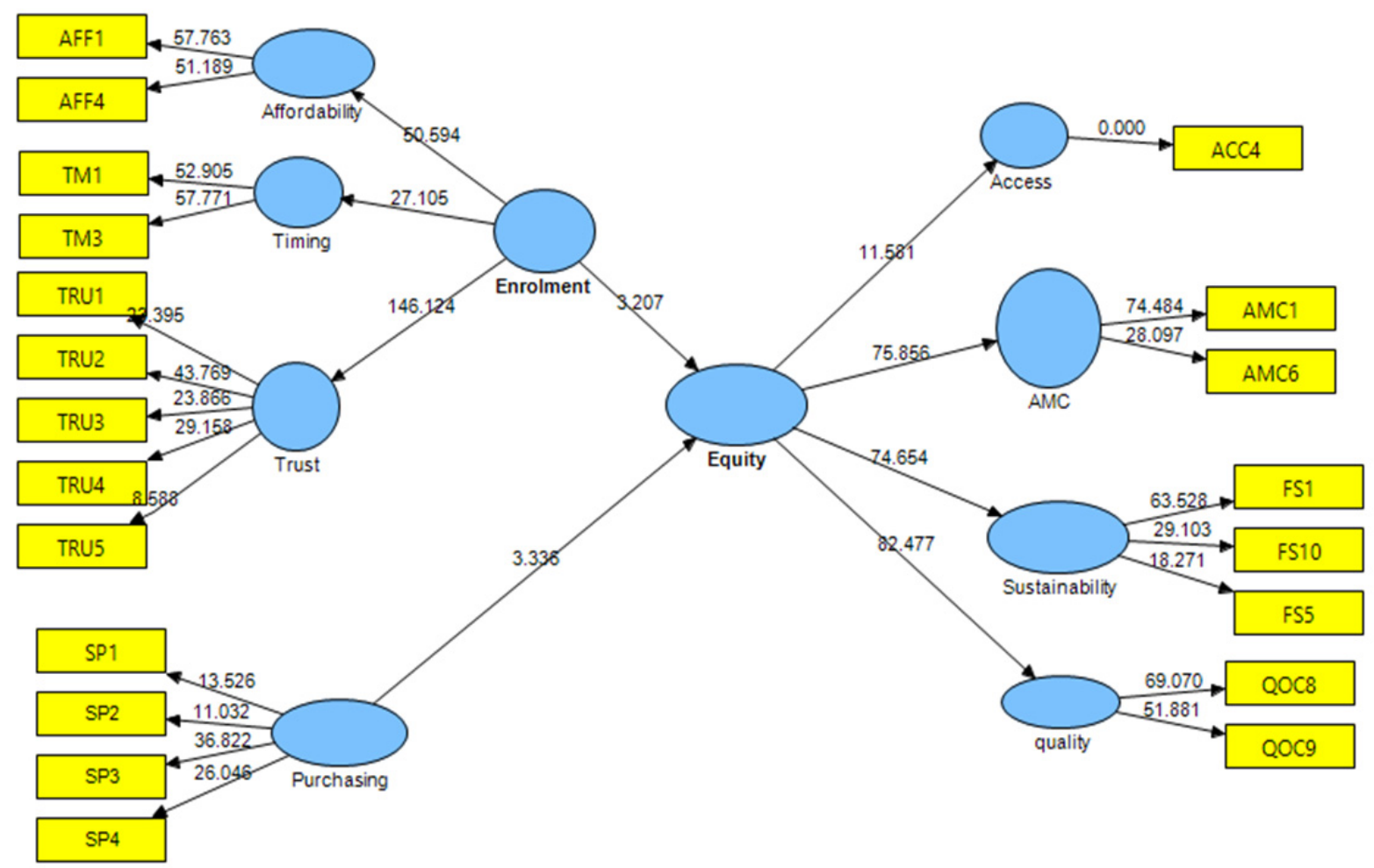

Figure 2. t- values for the optimum model without moderation

\subsection{Optimum Moderated Model}

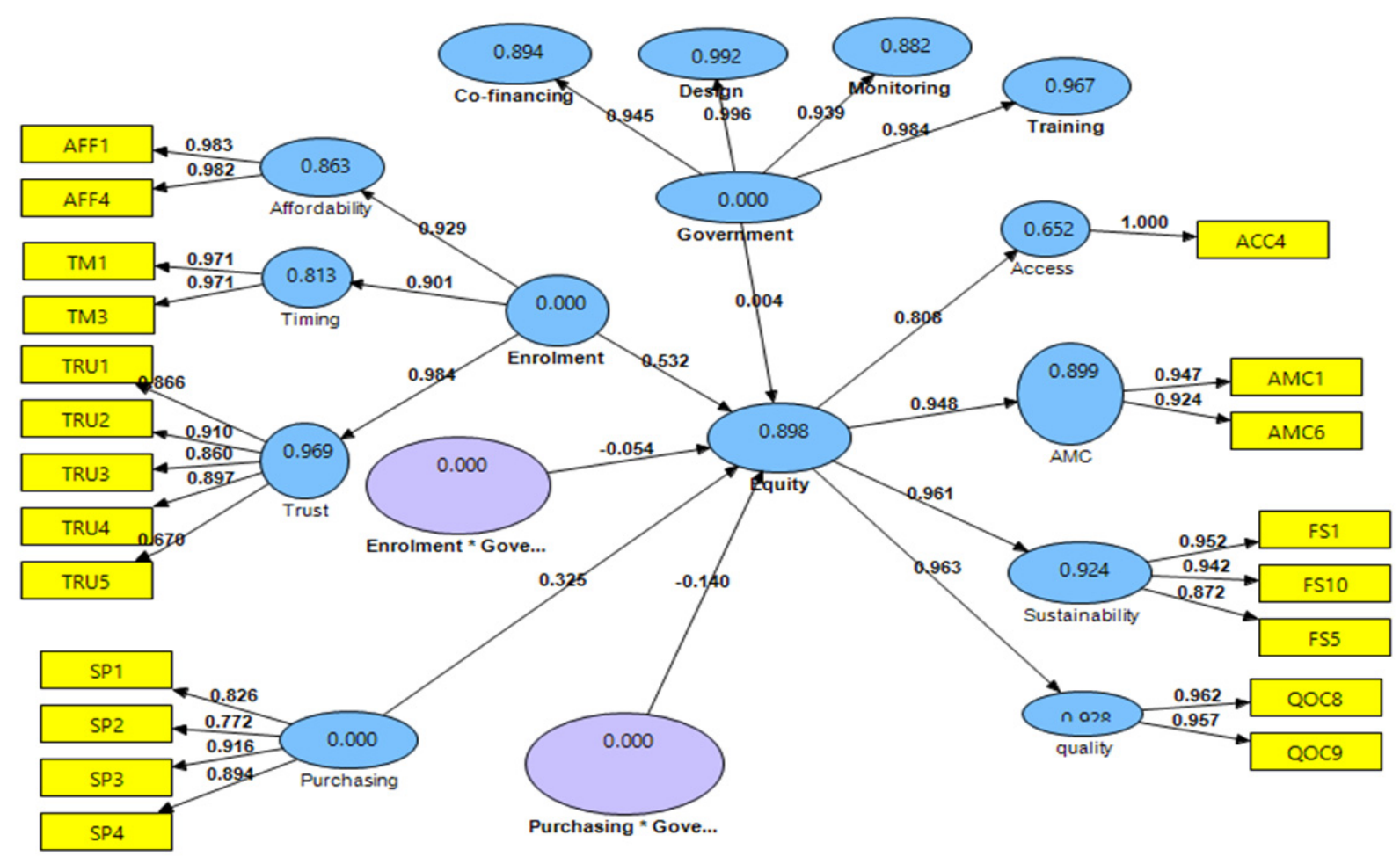

Figure 3. Path coefficients for the optimum moderated model 


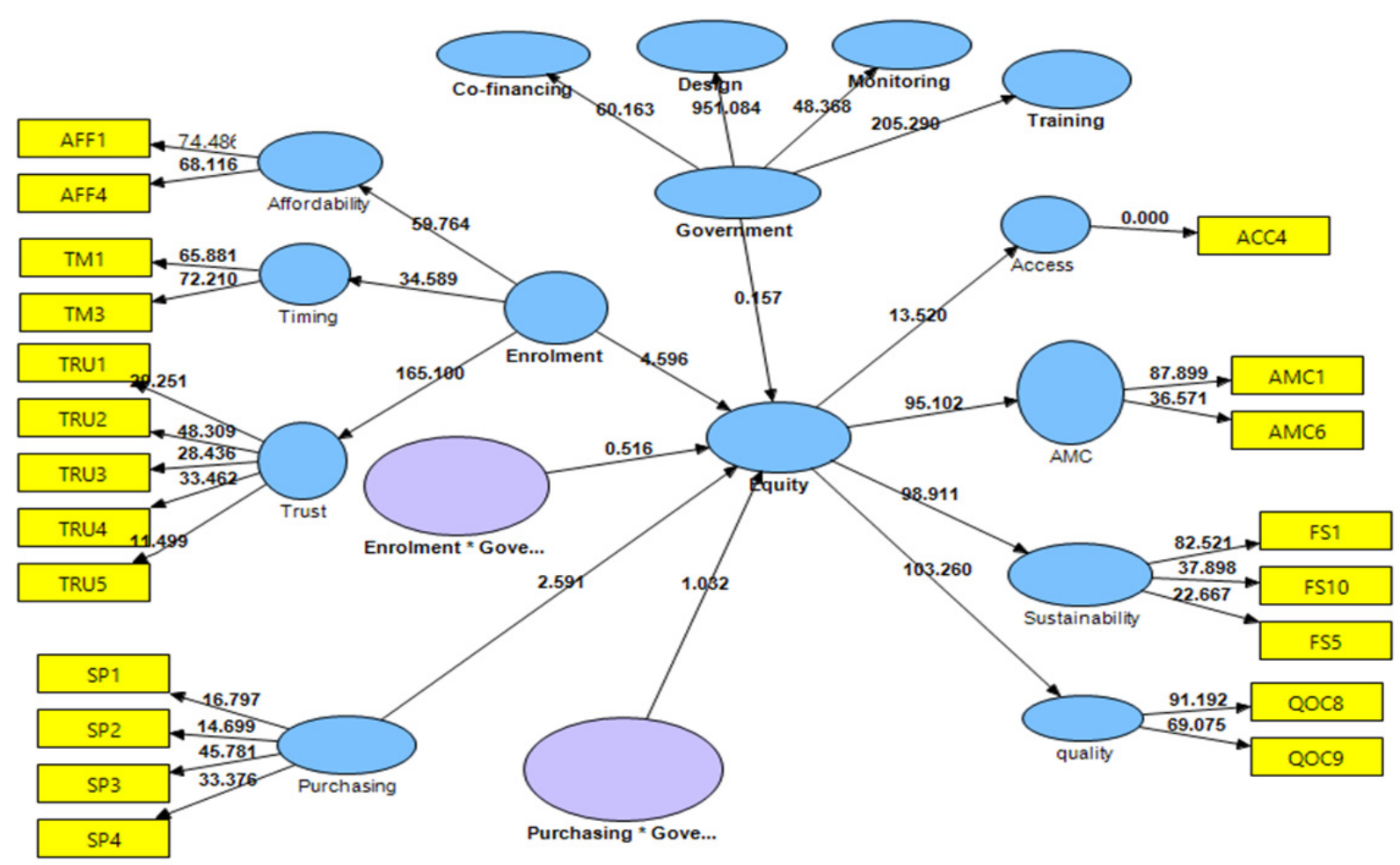

Figure 4. t-values for the optimum moderated model

Table 5. Path Coefficients (Mean, STDEV, t-values)

\begin{tabular}{|c|c|c|c|c|c|}
\hline & $\begin{array}{l}\text { Original } \\
\text { Sample (O) }\end{array}$ & $\begin{array}{l}\text { Sample } \\
\text { Mean (M) }\end{array}$ & $\begin{array}{l}\text { Standard } \\
\text { Deviation } \\
\text { (STDEV) }\end{array}$ & $\begin{array}{l}\text { T } \quad \text { Statistics } \\
(\mid \text { O/STDEV } \mid)\end{array}$ & P Values \\
\hline Enrolment*Gov -> Equity & -0.054218 & -0.05422 & 0.105034 & 0.516191 & 0.60595 \\
\hline purchasing*Gov -> Equity & -0.139900 & -0.01541 & 0.135515 & 1.032357 & 0.302405 \\
\hline
\end{tabular}

Figure 3 shows that the endogenous latent variable health equity had a coefficient $\mathrm{r}^{2}$ mean of 0.898 implying that the two exogenous variables, Enrolment and Strategic Purchasing explain $89.8 \%$ of variation in health equity. This represents an improvement in the variation explained compared to when the moderating variable, government stewardship is excluded ( $\mathrm{r}^{2}$ increases by $\left.7 \%\right)$.

Under moderation, Enrolment account for $53.2 \%$ of variation in Health Equity, while Strategic Purchasing account for $32.5 \%$ of variation of Health Equity. This presents a slight improvement in variation explained by Enrolment $\left(\mathrm{r}^{2}\right.$ increases by $\left.5.9 \%\right)$ while the variation of health equity accounted by Strategic Purchasing decreases by $17 \%$. Figure 4 suggests that the hypothesized paths between Enrolment and Health Equity $(\beta=4.596)$ and Strategic Purchasing and Health Equity $(\beta=2.591)$ are significant at 0.05 level of significance.

\section{Discussion}

The finding shows that government stewardship in CBHIs had positive effect on the relationship between enrolment and strategic purchasing and health equity in Kenya. This suggests that despite the lack of a clear legal and regulatory framework on how the role of CBHIs as complementary health financing organizations, other existing legal and regulatory framework in the insurance industry (particularly in micro-insurance) may be influencing how the health financing functions are executed in CBHIs. In particular, the existence of social capital that is inherent in the community has fostered enrolment (Chen et al., 2012), while purchasing services from providers accredited by NHIF (the main public insurer) influences strategic purchasing. The studied CBHIs have enrolled 12,101 households in partnership with NHIF; the partnership diversifies the mix of contributions. This evidences the complementary role that CBHIs play in extension of coverage as reported in Preker \& Carrin (2004). 
They had also employed cost effective methods of purchasing health services and had merged into networks. The networks enhance risk pooling to some extent. The study reveals that these practices had increased access to healthcare, improved quality of care and ensures equity in contributions.

Absence of government stewardship in diversification of mix of contributions has however hampered the role played by CBHIs in extending health equity to the precluded groups. For instance, absence of subsidies and or exemptions has resulted to exclusion of the poorest and socially excluded segments of the community (Carrin et al., 2005; Mladovsky \& Mossialos, 2006).

\section{Conclusion}

CBHIs plays a complementary role of extending health insurance to the preclude segments. The government through the ministry of health has the ultimate responsibility of ensuring all segments of its population obtain the services that they need without suffering financial ruin associated with their utilization. Hence, it is the responsibility of the government to guide the operation of CBHIs particularly in inclusion of the poor and vulnerable groups by providing the necessary policy framework within which the CBHIs should operate. This will require enacting the necessary legal and regulatory framework to guide CBHIs administrative and fiscal structures within the national health financing policy.

\section{Competing Interests Statement}

The authors declare that there are no competing or potential conflicts of interest.

\section{References}

Asante, A., Price, J., Hayen, A., Jan, S., \& Wiseman, V. (2016). Equity in Health Care.

Bennett, S., Creese, A., \& Monash, R. (1998). Health Insurance Schemes for Poeple outside Formal Sector Employment. ARA Paper No.16. Geneva: World Health Organization.

Carrin, G., Waelkens, M., \& Criel, B. (2005). Community-based health insurance in developing countries: a study of its contribution to the performance of health financing syste. Tropical Medicine and International Health, 10(8), 799-811. https://doi.org/10.1111/j.1365-3156.2005.01455.x

Kruk, M.E., Goldmann, E., \& Galea, S. (2009). Borrowing and Selling to Pay for Health Care in Low- and Middle-Income Countries. Health Affairs, 28, 1056-66. https://doi.org/10.1377/hlthaff.28.4.1056

Mladovsky, P., \& Mossialos, E. (2006). A conceptual framework for community-based health insurance in low-income countries: social capital and economic development. London: LSE Health, The London School of Economics and Political Science.

Pauly, M. V., Zweifel, P., Scheffler, R. M., Preker, A. S., \& Bassett, M. (2006). Private health insurance in developing countries. Health Aff (Millwood), 25, 369-79. https://doi.org/10.1377/hlthaff.25.2.369

Preker, A. S., \& Carrin, G. (2004). Health Financing for Poor People: Resource Mobilization and Risk Sharing. Washington. D. C: World Bank.

Starfield, B. (2011). The hidden inequity in health care. International Journal for Equity in Health, 10, 15. https://doi.org/10.1186/1475-9276-10-15

World Health Organization. (2000). The World Health Report 2000 - Health systems: improving performance. Geneva: World Health Organization.

World Health Organization. (2010). Health Systems Financing - The path to universal coverage. Geneva: World Health Organization.

World Health Organization. (2015a). Tracking Universal Health Coverage: First Global Monitoring Report. Geneva: WHO.

World Health Organization. (2015b). Do health expenditures meet health needs? Geneva: WHO.

World Health Organization. (2015c). Positioning health in the post-2015 development agenda. Geneva: WHO.

\section{Copyrights}

Copyright for this article is retained by the author(s), with first publication rights granted to the journal.

This is an open-access article distributed under the terms and conditions of the Creative Commons Attribution license (http://creativecommons.org/licenses/by/4.0/). 